\title{
THE LAW OF THE OIKOS. JACQUES DERRIDA AND THE DECONSTRUCTION OF THE DWELLING
}

\section{A B S T R A C T}

This paper sketches out the essential lines of a work in progress that aims at following the path opened up by Derrida on the deconstruction of dwelling. I intend to show how Derrida's concern for architecture is strictly bound to the urgency of deconstruction of dwelling that inhabits his work from at least Plato's Pharmacy (1966) on. According to Derrida, both philosophy and architecture are subordinated to an archaic conception of dwelling, which still haunts our way of thinking and building the dwelling (territory, city, house) and, thus, affects the political dimension of our life. 
This essay aims to account for a work in progress on the philosophies of dwelling that have had certain influence on architecture from Plato to Derrida, and beyond. In my view it should be articulated as a work of deconstruction inspired by Derrida.

Here I would like to demonstrate that Derrida's concern for architecture is justified by a specific reason: the question of dwelling. And, therefore, to demonstrate, that this question is at the very origin of deconstruction. Finally, that the deconstruction of architecture is a necessary moment of deconstruction itself.

To this extent, quoting Derrida from Point of folly, I recall that "Any consequent deconstruction [...] would do little if it did not go after architecture."1

In fact, in Point of Folly Derrida maintains that architecture, is "the last fortress of metaphysics." 2

But he also says that what we deem the essence and sense of architecture to be is in fact the legacy of a specific, historical determination:

Down even to its archaic foundation, the most fundamental concept of architecture has been constructed. This naturalised architecture is bequeathed to us: we inhabit it, it inhabits us, we think it is destined for habitation, and it is no longer an object for us at all. But we must recognise in it an artefact, a construction, a monument. [...]. This architecture of architecture has a history; it is historical through and through. Its heritage inaugurates the intimacy of our economy, the law of our hearth (Oikos), our familial, religious and political oikonomy, all the places of birth and death, temple, school, stadium, agora, square, sepulchre. It goes right through us to the point that we forget its very historicity: we take it for nature. ${ }^{3}$

Therefore, architecture is not simply "the last fortress of metaphysics" as such, by essence or necessity. It has become after being submitted to a certain law of dwelling:

The experience of meaning must be dwelling, the law of oikos, the economy of men or gods. [...]. the arrangement, occupation and investment of locations must be commensurated to this economy. [...]. Centred and hierarchized, the architectural organisation had to fall in line with the anamnesis of the origin and the seating of the foundation. Not only from the time of its foundation on the ground of the earth but also since its juridical-political foundation, the institution which 
commemorates the myths of the city, heroes or founding gods. Despite appearances, this religious or political memory, this historicism, has not deserted architecture. Modern architecture retains nostalgia for it: it is its destiny to be a guardian. An always-hierarchizing nostalgia: architecture will materialise the hierarchy in stone or wood (hylè); it is a hyletics of the sacred (hieros) and the principle (arché), an archi-hieratics. ${ }^{4}$

It is evident that here Derrida refers to a precise law of dwelling, which is historically determined: the law of the Greek oikos. A law that is rooted in an archaic or mythical-religious experience of space and place which is so powerful as to govern still the distribution of the spaces and places that identify individuals and the community with a certain territory.

In order to grasp the depth and, above all, the bearing of that law, it is important to outline that, for Derrida, it does not work only for architecture; yet, all aspects of our culture and, thus, of philosophy are subjected to this law.

However, architecture for Derrida is so important since:

The architecture forms its most powerful metonymy; it gives it its most solid consistency, objective substance. By consistency, I do not mean only logical coherence, which implicates all dimensions of human experience in the same network: there is no work of architecture without interpretation, or even economic, religious, political, aesthetic or philosophical decree. But by consistency I also mean duration, hardness, the monumental, mineral or ligneous subsistence, the hyletics of tradition. ${ }^{5}$

Deconstructing architecture means, therefore, deconstructing the law of the oikos that determines the essence of architecture in our tradition and, at the same time, means realizing the most general aim of deconstruction.

From this perspective, and here you have my hypothesis, Derrida proposes to Peter Eisenman to start collaboration with reading of Plato's Timaeus and his commentary. The text I am referring to is $K h \bar{o} r a^{6}$.

The choice of Timaeus is very accurate: it is one of the fundamental texts of the philosophical tradition as well as of architectural one (in particular, for one of its highest moments, the Renaissance).

In the Timaeus we find the metaphor of the demiurge as "divine architect" that brings the ideal into the sensible through calculation and geometry. In Timaeus we also find a paradigmatic analogy between the human body and the 
structure of the building and the city, an analogy which rests on the medical school of Cos, which, through Plato, imposes the law of the central and hierarchized symmetry to the construction of discourse as well as to sculpture and architecture.

More generally, it is in Timaues that the question of khöra establishes the coordinates of the Western speculation on space, taking its leave from Aristotle's criticism up to the Cartesian notion of space as the condition of res extensa and, thus, to Heidegger, who sees Plato's khöra at the origin of the metaphysical determination of space. ${ }^{7}$

For this reason Heidegger deemed necessary to get back to the original Greek conception of dwelling in order to gain an experience of space that would be non-metaphysical and to start from there to rethink of dwelling itself.

In my view, Derrida claims to return to khöra in order to acknowledge that philosophy, as well as architecture, have been submitted to the archaic law of dwelling, which one must not return to, as Heidegger suggests, but deconstruct and conjure away, in view of another dwelling, a dwelling to come.

In Point of Folly Derrida precisely demarcates his position from that of Heidegger on the question of the law of the oikos:

Heidegger still alludes to it when he interprets homelessness (Heimatlosigkeit) as the symptom of onto-theology and, more precisely, of modern technology. [...]. This is not a deconstruction, but rather a call to repeat the very fundamentals of the architecture that we inhabit, that we should learn again how to inhabit, the origin of its meaning. ${ }^{8}$

Before returning to Khōra, let me remark that Derrida began to deal with the law of the oikos much earlier than he met architects. I think that it is possible to reframe the whole path of deconstruction in light of this question. It is particularly evident in Plato's Pharmacy (1966) which ends up announcing the work on khora that Derrida would complete twenty years later.

First, Derrida makes a brave and, in my view, notable point: the system of conceptual opposition that constitutes the Platonic metaphysics rests on a nonconceptual opposition, which Plato himself does not develop in conceptual terms as it cannot be done:

In order for these contrary values (good/evil, true/false, essence/ appearance, inside/outside, etc.) to be in opposition, each of the terms 
must be simply external to the other, which means that one of these opposition (the opposition between inside and outside) must be already accredited as the matrix of all possible opposition. And one of the elements of the system (or of the series) must also stand as the very possibility of systematic or seriality in general. ${ }^{9}$

At the foundations of the system of metaphysics there is a spatial opposition, the inside/outside opposition, which is not purely conceptual but sensible, empirical, coming from such an ordinary experience as to appear obvious to Plato himself.

According to Derrida, here one can find the testimony of this experience of space in the archaic rituals of purification of the city, which survived in the polis of the classic age. Derrida writes:

The Character of the Pharmakos has been compared to a scapegoat. The evil and the outside, the expulsion of the evil, its exclusion out of the body (and out of) the city - these are the two major senses of the character and of the ritual. [...]. The city's body proper thus reconstitutes its unity, closes around the security of its inner courts, gives back to itself the word that links it with itself within the confines of the agora, by violently excluding from its territory the representative of an external threat or aggression. That representative represents the otherness of the evil that comes to affect or infect the inside by unpredictably breaking into it. Yet the representative of the outside is nonetheless constituted, regularly granted its place by the community, chosen, kept, fed, in the very heart of the inside [...]. The ceremony of the pharmakos is thus played out on the boundary line between inside and outside which it has as its function ceaselessly to trace and retrace. Intra muros/extra muros. ${ }^{10}$

Here it is possible to grasp the origin of the law of the oikos: the mythicalreligious experience which still survives in the organization of the space of polis, and, at the same time, makes the paradigm of the ontological identity understood as a permanent and stable presence, independent and autonomous from the alterity to which it is detached as the inside from the outside.

But it is necessary to return to Khorra to understand the phantasmatic ground (which is powerful as much as illusory), that, according to Derrida, still haunts our dwelling. At least this is the hypothesis I aim to verify. 


\section{POLITICS OF KHORA}

But, in order to grasp the political dimension of the Timaeus and of the ontological question posed in Khora, it is necessary to refer to other texts, which are still unpublished and which I have recently discovered in the Derrida-archives.

In particular, I am referring to a seminar of 1985-86 entitled Nationalité et nationalisme philosophique: mythos, logos, topos, whose first six sessions focus on the Timaeus and the question of khorra. In fact the text proposed to Eisenman is a quite bizarre editing of excerpts from this seminar. Here one can see that the stakes of Derrida's reading are political.

In fact, the Timaeus continues a dialogue that took place the day before, where Socrates described "the ideal polis and its constitution" , and which can be identified with the Republic.

Since the first conversation we know that the dialogues take place during the Panathenian celebrations, which had the character of a National celebration and involved the entire population. The celebration was devoted to Athena, the goddess founder and protector of the city. A spectacular procession used to climb the acropolis up to the temple of Athena where an impressive sacrifice was offered in order to celebrate the divine origin of the city and to renew the alliance with the protector goddess. In particular, the core of the cult was the myth of the autochthony of Athenians ethnicity: that is, by the myth of Erichtonius who was born directly from earth, not from a woman, but from the soil fecundated by the seed of Hephaestus, which was dispersed after his clumsy attempt to possess Athena.

At the top of the acropolis, in the archaic age, the Erecteion was the oldest temple and it was dedicated to those myths of foundation and, thus, also to the cult of Erichtonius, the king-God of the origins. When in the classical age it would be rebuilt in another place, the original foundations will be preserved.

Therefore, during the Panathenian celebrations, the people of Athens, the sons of the earth, celebrated at the same time the divine and autochthonous origin of their genos, which makes them exceptional and superior with respect to the other Greeks. 
As it is well known, Cimon, first, and then Pericles invested huge capitals to rebuild the acropolis after its destruction by the Persians. In order to restore its symbolical value and thus to remove the trauma inflicted to the Athenian identity by the foreign invasion. The most important architects of that age were involved in the work of reconstruction, which can be seen as a paradigm of Western architecture. The whole architectural organization seems structured according to that symbolical project, which found in the Panathenian celebrations its concrete and spectacular realization. In particular, in the processional ascension, that we find represented as a divine procession in the extraordinary, internal frieze of the Parthenon, which was realized by Phidias and his disciples ${ }^{12}$.

In the seminar devoted to the Timaeus Derrida lingers on this celebration, on its spatial organization and its archaic cause, at the roots of the myth of autochthony ${ }^{13}$. In particular, he focuses on the itinerary of the procession along the sacred way (fig.f). The procession leaves from the lower city, from the Ceramic, where the famous Athenians are buried, passes by the agorà, the secularized space of the political, and goes up to the acropolis and ends up before the impressive statue of Athens.

The remark by Derrida is the key to understand what is at stake here:

At the ceramic, in the civic ground (khōra) they come from, the sons of the polis are buried: time annihilates through the return of the end to the origin. ${ }^{14}$

I underline the word between brackets: the civic ground is named khōra. We should read the Timeus from this perspective.

This is the subject of the dialogue: it had to sketch out, along with the Critias, never finished, and, perhaps, with the Hermocrates, which has never been written, the complete table which would make possible the passage into the historical reality of the perfect city of which Socrates described the ideal traits in the Republic and, briefly, at the beginning of the Timaeus.

This general table responds to an urgent political necessity: Timaeus and Critias will have to expose the possibility to put the ideal polis into act in the historical becoming, the possibility of the passage from ideal to sensible. This possibility must be founded on the origin and structure of the universe and, thus, on the origin and the history of the city which must actualize it, namely, Athens. 
Socrates himself delineates in these terms the order of the dialogue and the tasks of the interlocutors: Timaeus performs the onto-cosmological reconstruction, from the origin of the universe to the anthropological structure of man; while Critias must reconstruct the origin of the people of Athens and their history.

Therefore, Plato aims to demonstrate the congruity of his ideal and political construction with the ontological foundations of all that is, and thus the possibility for the concrete actualization of the ideal in a specific place: Athens. But, one can also suppose that the ontological, cosmological, anthropological determinations are constructed so as to suit the possibility of the actualization of the ideal polis.

Let us follow the initial lines of the Timaeus to the point when Socrates assigns Timaeus and Critias the task to make sensible the ideal polis.

He has just summed up the essential passages of the discourse held the day before on "the city - politeia - and its constitution".

At this point, Socrates lets his interlocutors speak: he describes the essence of the perfect polis, but this is only a fixed, motionless and lifeless image (hypo graphés). Now, it is time to make it lively, to bring it from essence to existence. This passage is decisive: the essence of polis takes its life in war. War is the proof against which one must measure the possible actualization of the political ideal:

I should like to hear an account of it putting forth its strength in such contests as a State will engage in against others, going to war in a manner worthy of, and achieving results befitting, the training and education given to its citizens, both in fears of arms and in negotiation with various other States. ${ }^{15}$

War and, thus, the affirmation and defence of one's identity against the identity of others, this is the goal of the ideal construction of the polis and, therefore, the ground on which the very constitution of the polis lies and organizes itself. Derrida writes:

To give birth-but this is also war. And therefore death. This desire is also political. How would one animate this representation of the political? [...].The possibility of war makes the graphic image (hypo graphés) - the description - of the ideal city go out, not yet into the living and mobile real, but into a better image, a living image of this living and mobile real, 
while yet showing a functioning that is internal to the test: war. In all the senses of the word, it is a decisive exposition of the city. ${ }^{16}$

The ideal determination of the city must be verified through its existence and this existence, the life of the ideal city, consists of war. The relationship with the other cities is thought in terms of conflicting opposition. The other as such is stranger and foreigner, a threat for the life of the city, which is conceived as interiority with respect to a certain outside. At this point, Socrates, distributes roles and duties which will be carried out by his interlocutors. First, he excludes that this task could be fulfilled by poets (poiettikon genos) since they are a genos of imitators (mimêtikon ethnos). But, above all, he claims to establish the genos authorized to say the truth against the genos of sophists:

I am aware that the Sophists (sophistōn genos) have plenty of brave words and fair conceits, but I am afraid that being only wanderers from one city to another, and having never had habitations of their own (oikēsis idias), they may fail in their conception of philosophers and statesmen, and may not know what they do and say in time of war, when they are fighting or holding parley with their enemies. And thus people of your class (genos) are the only ones remaining who are fitted by nature and education to take part at once both in politics and philosophy. ${ }^{17}$

The true logos about the polis can be performed only by the genos that occupies permanently, since birth, its original place. Derrida writes:

Socrates privileges here again the situation, the relation to place: the genus of sophists is characterized by the absence of a proper place, an economy (oikonomia), a fixed domicile; these people have no domesticity. No house that is proper to them (oikêsis idias). They wander from place to place, from town to town, incapable of understanding these men who, being philosophers and politicians, have (a) place [ont lieu], that is, act by means of gesture and speech, in the city or at war. ${ }^{18}$

Therefore, the legitimacy of the discourses (logoi) authorized to say the truth of the polis depends on their belonging to a certain philosophic/political genos. And the determination of this belonging, which grounds the very legitimacy of the true logos, is the determination of the belonging to one's own original place. This belonging refers to the order of dwelling, it is linked to the oikos, to the familiar nucleus as original community, which is the constitutive element of polis. Belonging is given by birth or education. It stands against one's differing from oneself which characterizes the genos of sophists, who wander from a city to another and have no proper place (oikēsis idias). 
At this point it is clear, or, at least, it should be so, that the archaic ghost affecting ontology and politics binding the one to the other, comes from an archaic experience of dwelling and, thus, of community. This law imposes to think identity (the ontological and political identity) in terms which are irreducibly spatial: origin as a place, permanence, stability, being distinguished and protected from difference, alterity, the stranger, the foreign.

Later on, indeed, while opening his discourse on the origin and structure of universe, Timaeus affirms the fundamental ontological distinction and defines the two opposite genera of being into which everything that is solves: the ideal and the sensible.

Stability and permanence, immutable identity, are the ontological traits of the ideal being against the sensible being, which, conversely, corresponds to the order of becoming and, thus, is always changeable and differing from itself like the sophist. ${ }^{19}$

At this point, it remains to show how this law also determines the ontological question of khōra.

\section{THE PHANTASM OF THE ORIGIN}

Let me sum up shortly the context of the question: Timeus in the first part of his discourse, once posited the capital ontological distinction between the ideal and the sensible, being and becoming, introduces the figure of the Demiurge, that staring at the ideal gives shape to the sensible.

However, at the heart of his discourse, Timaeus investigates more in-depth the question: how does this passage happen? He must hypothesize a third genus, neither ideal, nor sensible, through which the passage takes place and names it khōra.

As it is neither sensible nor ideal, not even a being, it cannot be determined in any way as a being could be. For this reason, to describe it, Timaeus must use a set of analogies (the receptacle, the cast, the sieve, the nurse, etc.) assuming that none of them is adequate since they all come from the sensible which is determined in the khorra. It remains indeterminate: the indeterminate, which preventing itself from any possible determination, makes every determination possible. But, at the same time, in its indeterminateness khöra imposes on us to think that all that is, is as it takes place, as it has an origin which remains fixed, permanent and stable, has a proper place, oikēsis idias. 
In the above mentioned seminar, Derrida is more explicit:

If khora can receive everything, if it can become everything, one could ask why Timaeus insists on the necessity of a unique appellation. Perhaps, because it can receive everything, one could give it all the names one wants, since it can take any form, ultimately one could give a name different from Khora. As it does not exist under the form of a being identical with itself, of an ideal referent or a thing, one does not see why it would have only one name. But it is precisely because of this that it is always necessarily to name it in the same way, since it is paradoxically necessary to keep the sense that it has no sense, to prevent one from puzzling it with what it receives and that it is not, so it is absolutely necessary for the law of discourse to name it always in the same constant and identifiable way in order not to confuse it with what it receives, with the forms it can take and, thus, it is necessary to name it always in the same way, it is necessary that language always points to that unique thing which is not a thing, which cannot be confused with anything, etc. Therefore, naming it in the same way means to maintain paradoxically the same reference to what cannot ever be a real and determinate referent, a particular referent, a singular one. ${ }^{20}$

In the seminar, referring to Critias's story about the act of foundation of the city, in relation to Athena's choice about the place, Derrida observes that "this choice decides everything" ${ }^{\prime 21}$ and, thus, puts into relief a first anticipation of the future, apparently ontological, question of khōra.

The discourse of Critias, maintains Derrida, "has already presented itself as a discourse about khöra even before khorra as such becomes the subject of the general discourse"22.

In this perspective, the choice of the name khorra seems surreptitiously conditioned since the preamble of Timaeus, where Socrates resumes the speech on the ideal polis, and where the term first appears, long time before Timaeus's onto-cosmogonist discourse. In the preamble Socrates describes briefly the law that regulate wedding and education: it is necessary to raise the sons of the better and take the others to another country, giving everybody his proper place. This place is called by Socrates "khōran"23.

In this first occurrence, khōra, according to its semantic spectre, refers to the occupation of a place; it describes the borders of an inhabited territory against a wild space. Derrida writes: 
Although the word was already uttered (19a), the question of khorra as a general place or total receptacle is, of course, not yet posed. But if it is not posed as such, it gestures and points already. The note is given. For, on the one hand, the ordered polysemy of the word always includes the sense of political place or, more generally, of invested place, by opposition to abstract space. Khöra "means": place occupied by someone, country, inhabited Place, marked place, rank, post, assigned position, territory, or region. And in fact, Khōra will always already be occupied, invested, even as a general place, and even when it is distinguished from everything that takes place in it. ${ }^{24}$

Finally, for Plato, it is not important to establish what khorra is, but that there is a proper place, an unique origin which is identical with respect to itself, stable and permanent, an origin which, remaining indeterminate in itself, institutes the criterion of every possible ontological determination: the identity understood as stability and permanence.

In this way, the law of the oikos secretly founds ontology and, thus, our experience and conception of the dwelling. A law but also an archaic phantasm to which no reality corresponds, as no reality can correspond to the myth of Erichtonius, the myth of autochthony, which founds the political identity of Athens. And which still haunts our experience and conception of the dwelling and of the architecture ${ }^{25}$.

It is to this law, its archaic phantasm that Derrida refers to in Specters of Marx, in a passage in which he purposes a formalization of it:

Inter-ethnic wars (have there ever been another kind?) are proliferating, driven by an archaic phantasm and concept, by a primitive conceptual phantasm of community, the nation-State, sovereignty, borders, native soil and blood. [...]. But how can one deny that this conceptual phantasm is, so to speak, made more out-dated than ever, in the very ontopology it supposes, by tele-technic dis-location? (By ontopology we mean an axiomatic linking indissociably the ontological value of present $\sim$ being [on] to its situation, to the stable and presentable determination of a locality, the topos of territory, native soil, city, body in general). ${ }^{26}$

And a little bit later Derrida invites us to rethink of dwelling in the wake of an experience of place and space which is more original than the one imposed by the law of the oikos, an experience that the law of the oikos removed in the phantasmatic desire of an autochthonous identity, that is, pure and immune 
from any relation to the other in general:

All stability in a place being but a stabilization or a sedentarization, it will have to have been necessary that the local différance, the spacing of a displacement gives the movement its start. And gives place and gives rise [donne place et donne lieu]. ${ }^{27}$

This means that we must rethink of dwelling by leaving from différance as the condition of spacing and, thus, of taking place in general. In this perspective, we would have to come back to Of Grammatology, in particular where Derrida suggests a new transcendental aesthetic, that would be based on an experience of the space more original than that of the geometrical space that governs the Western conception of space. A more original experience of the space that has nothing to do with the Heideggerian perspective, insofar as Derrida relates it to the Leroi-Gourhan's paleontological research:

A new transcendental aesthetic must let itself be guided not only by mathematical idealities but by the possibility of inscriptions in general, not befalling an already constituted space as a contingent accident but producing the spatiality of space. Indeed we say of inscription in general, in order to make it quite clear that it is not simply the notation of a prepared speech representing itself, but inscription within speech and inscription as habitation always already situated. Such a questioning, in spite of its reference to a form of fundamental passivity, ought no longer to call itself a transcendental aesthetic, neither in the Kantian, nor in the Husserlian, sense of those words. A transcendental question on space concerns the prehistoric and pre-cultural level of spatio-temporal experience which furnishes a unitary and universal ground for all subjectivity, and all culture, this side of empirical diversity, as well as the orientations proper to their spaces and their times. ${ }^{28}$

I started to go through this way elsewhere ${ }^{29}$, here I would like to conclude pointing out that, for Derrida, the deconstruction of the onto-topo-political paradigm is at the basis of his interest about architecture, as shown at the end of his polemical speech given in Japan at the conference organized by $A N Y$ Corporation and titled Anywhere:

How is it possible to re-politicize the architectural theory or practice just de-constructing a certain concept of the political, even of democracy? The question may disclose enormous and unending tasks, but it must remain open: that is a necessity and an obligation. This "must" is more original and important than the question it bears and makes possible. It gives the question its opening. It cannot be but the opening to the other, 
to the other to which it addresses itself or from where it comes; opening from the other and to the other and, thus, to the future, to the otherness that cannot be anticipated, to the possibility of surprise without which there would be no opening. Deconstruction, or if you like, re-building does not only get through discourses. It proceeds also from what is coming and has not come yet, through events and inventions. Future, invention, event, that require a re-politicizing deconstruction of the political, must open calculus, project, program, rule and law on what must remain non-calculable. To open them does not mean to put them out of play or destroy them. It has to do with another gesture, another movement, another relation to space. ${ }^{30}$

This is the task of the deconstruction of the dwelling, and, at the same time, the task of the architecture deconstruction appeals to. Association, 1985), 9.

Ibid.

Ibid., 7.

Ibid., 9.

Ibid.

It was first published in J. Kipnis and T. Leeser (Eds.), Derrida Eisenman. Chora L Works (London: Architectural Association, 1991). For a reading of Khōra from the architectural point of view see A. Vidler, "Nothing to do with Architecture," Gray Room 21 (2005), 112-127. 
On the Panathenian celebrations and their political role, see: A. Queyrel, Athènes. La cité archaïque et classique (Paris: Picard, 2003), 247-252.

It is worth remarking that, regarding the theme of the Athenian's autochthony, Derrida refers extensively to N. Loraux, The Children of Athena. Athenian Ideas about Citizneship \& the Division between the sexes, trans. by C. Levine (Princeton: Princeton University Press, 1993).

Jacques Derrida, Nationalité et nationalisme philosophique: mythos, logos, topos, unpublished seminar,"Derrida archives"(Caen: IMEC, 1986).

Jacques Derrida, 'Khōra," in Id., On the Name, trans. by I. McLeod (Stanford: Stanford

University Press, 1995), 118.

Plato, Timaeus, 19e.

Derrida, Khōra, 107.

see Plato, Timaeus, 27d-28a.

Derrida, Nationalité et nationalisme philosophique.

Ibid.

On the role played by Critias in the Timaeus see J. Sallis, Chorology. On Beginning in Plato's Timaeus (Bloomington and Indianapolis: Indiana University Press, 1999), 7-45.

Plato, Timaeus, 19a.

Derrida, Khōra, 109.

In the perspective of architecture, we agree with the conclusions drawn by Vidler in his mentioned article, but once discovered the law of the oikos, it is necessary to recognize that the "foundation of the polis" gives the rule for both architecture and onto-cosmology. See A. Vidler, "Nothing to do with Architecture", cit., p. 123: "The foundation of the polis, moreover, demands a replication of the cosmic constructs - the establishments of territories through geometry, their definition according to classes of inhabitants, and the careful exclusion of noncitizens of the polis into the worldly equivalent of chaos. In sum, the work of architecture".

Jacques Derrida, Specters of Marx. The State of the Debt, the Work of Mourning and the New International, trans. By P. Kamuf (New York - London: Routledge, 1994), 102.

Ibid., 103.

Jacques Derrida, Of Grammatology, trans. by G. Spivak (Baltimore-London: John Hopkins University Press, 1997), 290.

I'm referring to a seminar given at the State University of New York at Buffalo (April 2012) titled "Via Rupta: the Text and the Living". The first part is forthcoming in French with the title "Via rupta: vers la biodeconstruction”, in Appels de Jacques Derrida,ed. D. Cohen-Lévinas and G. Michaud (Paris: Hermann, 2013).

Jacques Derrida, 'Faxtexture," in Anywhere ed. C. C. Davidson (New York: Rizzoli

International,1992), 34. 
Derrida, Jacques. "Plato's Pharmacy." In Id., Dissemination, trans. By B. Johnson. LondonChicago: Athlone-Chicago University press, 1981.

Derrida, Jacques. "Point of Folly." In La case vide by B. Tschumi, London: Architectural Association, 1985.

Derrida, Jacques. Nationalité et nationalisme philosophique: mythos, logos, topos, unpublished seminar,"Derrida archives", Caen : IMEC, 1986.

Derrida, Jacques. 'Faxtexture." In Anywhere ed. C. C. Davidson. New York: Rizzoli International, 1992.

Derrida, Jacques. Specters of Marx. The State of the Debt, the Work of Mourning and the New International, trans. By P. Kamuf. New York-London: Routledge, 1994.

Derrida, Jacques. 'Khōra." In Id., On the Name, trans. by I. McLeod. Stanford: Stanford University Press, 1995.

Derrida, Jacques. Of Grammatology, trans. by G. Spivak. Baltimore-London: John Hopkins University Press, 1997.

Heidegger, Martin. An Introduction to Metaphysisc, trans. by R. Manheim. Garden City: Doubleday, 1961.

Plato. Timaeus, trans. by D. J. Zeyl. Indianapolis-Cambridge: Hackett, , 2000. 
JEVREJSKI ZID:

Ajzenmanovo carstvo

\section{Renato Rizzi}

U ovom radu, autor se zalaže da i arhitektura, kao i druge estetske discipline, već dugo ukazije na prvobitni problem: osećaj forme. Forma se smatra mnoštvom ekspresivnih jezika koji potiču od određene vrste znanja. Arhitektura je viđena kao rad realizacije, saznanje znanja, a forma je prezentacija, suština je u osećaju.

Autor tvrdi da je više promenljiv, mada ne jedini među četiri faktora, pravo na znanje. Ako se više ili manje proširi i produbi, veća je ili manja naša sposobnost da klizimo duž osnovne linije. Ili ka "sadržaju istine jednog dela", prema rečima Valtera Benjamina. Pretpostavka, iako tek treba da se dokaže, nameće logiku mišljenja kojoj treba pridružiti estetiku mišljenja: poklon sastavljanja, slika jedinstva celine.

U nekoliko delova, preko teoloških pitanja, scena mišljenja, tumačenja o zastupanju i razmišljanju, ideja, koncepata i fenomena, autor diskutuje o mogućim tumačenjima rada Pitera Ajzenmana.

KLJUČNE REČI: TELOS, IKONOLOGIJA, EPISTEMOLOŠKA PREMISA, FORMA, INTERPRETACIJA, TEOLOGIJA, JEVREJSKA PARADIGMA, GRČKO-HRIŠĆANSKA PARADIGMA

ARHITEKTURA I FILOZOFIJA:

Paradoksi i metamorfoze njihovog sastanka

\section{Chris Younès}

Poznato je da je Žak Derida (Jacques Derrida) istakao ideju suštinskog suživota između filozofije i arhitekture, izjavljujući: „Collège inetrnational de philosophie bi trebalo da obezbedi mesto za sastanke (recontre), sastanak razmišljanja, između filozofije i arhitekture. Ne da bi se konačno sukobljavale, već da se razmišlja o onome što ih je oduvek održavalo zajedno u najsuštinskijem suživotu." Ovaj rad se posebno bavi hipotezom o metamorfozi ovog sastanka da, od jedinstva arhitektonike i principa, postaje mnogostrukost i drugog karaktera. Tako da je tu preispitivanje u smislu granica i prolaza; drugim rečima, u smislu otvaranja. Prvi sastanak se može smatrati kao metaforička igra ogledala u kojoj svako predstavlja sebe kao prevlađujući u odnosu na druge oblike znanja - jedan kao nauke o teoriji, drugi kao nauke o tehnikama. Ovo uređeno i orijentisano poziranje će propasti u isto vreme sa nestankom konačnog kosmosa. U tom raspadu, arhitektura i filozofija su se 
prekomponovale da bi se bavile prostorom i vremenom naseljenih sredina koje utiču ne samo na konstituciju pogleda, već isto tako na transformaciju sveta. Istražuje se kako je njihov interfejs heuristička struktura ispitivanja.

KLJUČNE REČI: FILOZOFIJA, ARHITEKTURA, GRANICE, PROLAZI, METAMORFOZA

\section{MARGINE ARHITEKTURE}

\section{Maurizio Ferraris}

Polazeći od primera naročito ružne Palazzo Nuovo u Torinu, ovaj rad ima za cilj da predstavi, putem poređenja između arhitekture i vizuelnih umetnosti, deset interpretacija (konceptualnost, auralnost, suplementarnost, neodgovornost, pareregonalnost, autorijalnost, podređenost, dokumentalnost, piramidalnost, stvarnost), koje opisuju karakteristike savremene arhitekture kao što i ukazuju na određene granice i pravila sa kojima arhitektura mora da se pomiri.

KLJUČNE REČI: ARHITEKTURA, FILOZOFIJA, VIZUELNE UMETNOSTI,

DOKUMENTALNOST,STVARNOST, DERIDA, ESTETIKA

ZAKON OIKOSA.

Žak Derida i Dekonstrukcija Stanovanja

\section{Francesco Vitale}

Ovaj rad skicira bitne linije rada koji je u toku a koji ima za cilj da prati putanju koju je otviro Derida ka dekonstrukciji stanovanja. Nameravam da pokažem kako je Deridina briga za arhitekturu strogo povezna sa urgentnošću dekonstrukcije stanovanja koja naseljava njegov rad od najmanje Platonove Farmacije (1966), pa nadalje. Prema Deridi, i filozofija i arhitektura su podređene arhaičnoj koncepciji stanovanja koja još uvek opseda naš način razmišljanja i izgradnje mesta stanovanja (teritorija, grad, kuća) i, na taj način, utiče na političku dimenziju našeg života.

KLJUČNE REČI: STANOVANJE, DEKONSTRUKCIJA, KHORA, ONTO-TOPO-POLITIKA, PROSTOR

\section{LA NAVE DI PIETRA/ KAMENI BROD}

\section{Zoran Lazović:}

Svet se stalno gradi i razgrađuje. Da li postoji suštinski paradoks dekonstruktivizma u kreativnim radovima arhitekata? Čemu odgovara arhitektonski projekat? Dnevnik priče u kojoj je pripovedač svoj sopstveni tumač:Od neizvesnog prisećanja i izbledelih kopija do višestrukih novih 
originala. Gde je bio Vavilon arhitekte? Grupni portret. Kriegs Insel in Plannen, Isključenje iz zemaljskog Raja. Blok 24. Kulturni centar Tré́eg Milenijuma. Futuristički pristup Savskom amfiteatru Tré́eg Milenijuma. Urbana Utopija: Omaž gradu Vukovaru. Grad Nade. Cauchemare - košmar. Noćni rad. Imago mundi. Opservatorija budućnosti? Lutanje i život na niskoj frekvenciji. Beogradska Nekroza i Smrt Srbije. Paralela introspekcije, ili smrt mnogih svetova pred nama. Oni koji ne mogu da vide da će umiranje videti neke druge svetove kako nestaju: njihovo propadanje, rastavljanje, nestanak. Pogled u ambis prošlosti: radi nekog traga, ili radi nešto više tragova uporedno. Arhitektura. Slike. Fragmenti. Hibridi. Svedočenje očuvanih slika, objekata, arhitektonskih kompozicija, ikonografskih fragmenata, montaža, sklopova, umetničkih kolaža, mentol brikolaža. Odraz velikih događaja i ideja: neprekidno menjajujući i nestajući Kontekst. Kontekst velikih pokreta. Moda. Trendovi.Glavne tendencije. Ratovi. Kreativni prioriteti i vizije. Lekcija iz anatomije: sučavanje sa sopstvenim projektima i konstruktima, vezivanje, analiza, dekonstrukcija, reminiscencija i rekonstrukcija, se-ćanje (ponovno vraćanje delova celine). Neki trag već uništenog postojanja i neizbežnog nestajanja. Da li postoji iščekivanje i predviđanje događaja i raspadanje, odlazak i povratak? Kakvi su to ramovi imali slike koje su bile nevidljive u to vreme? Pratiti trag kroz Spektar Deride.

KLJUČNE REČI: ARHITEKTURA, IDEJE, KONCEPTI, KONTEKSTI, DEKONSTRUKCIJE, DESTRUKCIJE, RETROSPEKTIVA 